\title{
Ethnicity and aquatic lifestyles: exploring Southeast Asia's past and present seascapes
}

\author{
Tom Gunnar Hoogervorst
}

Received: 11 April 2012/Accepted: 21 June 2012 / Published online: 19 July 2012

(C) The Author(s) 2012. This article is published with open access at Springerlink.com

\begin{abstract}
This study explores the profound maritime dimension in Southeast Asia's past and present. It highlights the region's "sea people", giving special attention to their complex and dynamic interactions with terrestrial communities. Their cultures and aquatic lifestyles, it is argued, are relevant to understanding the wider context of various historical and contemporary issues in this region. Since the emergence of large-scale harbour polities in Sumatra, Borneo and other parts of insular Southeast Asia, nomadic maritime communities have intermittently appropriated the roles of protégés, outlaws and victims in a multilayered and multifaceted interplay of seaborne navigation, commerce and warfare. On the one hand, many of the interethnic power relations that helped shape the maritime history of Southeast Asia have remained intact to date and can help us understand a number of present-day phenomena. On the other, 19th and 20th-century developments have largely confined these communities to the margins of society, while their erstwhile "maritory" has become the battleground of competing "globalised" crime syndicates, maritime terrorists and post-independent nation states with modern navies. The seascapes of Southeast Asia are as dynamic as they are diverse.
\end{abstract}

Keywords Seascapes - Sea people $\cdot$ Sama-Bajau $\cdot$ Southeast Asia $\cdot$ Piracy · Ethnicity $\cdot$ Maritime terrorism $\cdot$ Sulu Sea

\section{Introduction}

Amidst the world's largest archipelago, history has continuously been shaped, dominated and punctuated by events that took place on the water. Even today, Southeast Asia is home to communities for whom life is predominantly spent ashore and afloat. Their houseboats, coastal stilt villages and sea-oriented economies form some of the last truly authentic exponents of the region's great maritime history. At the same time, many of these aquatic

T. G. Hoogervorst ( $₫)$

School of Archaeology, University of Oxford, Oxford, UK

e-mail: tomhoogervorst@ hotmail.com 


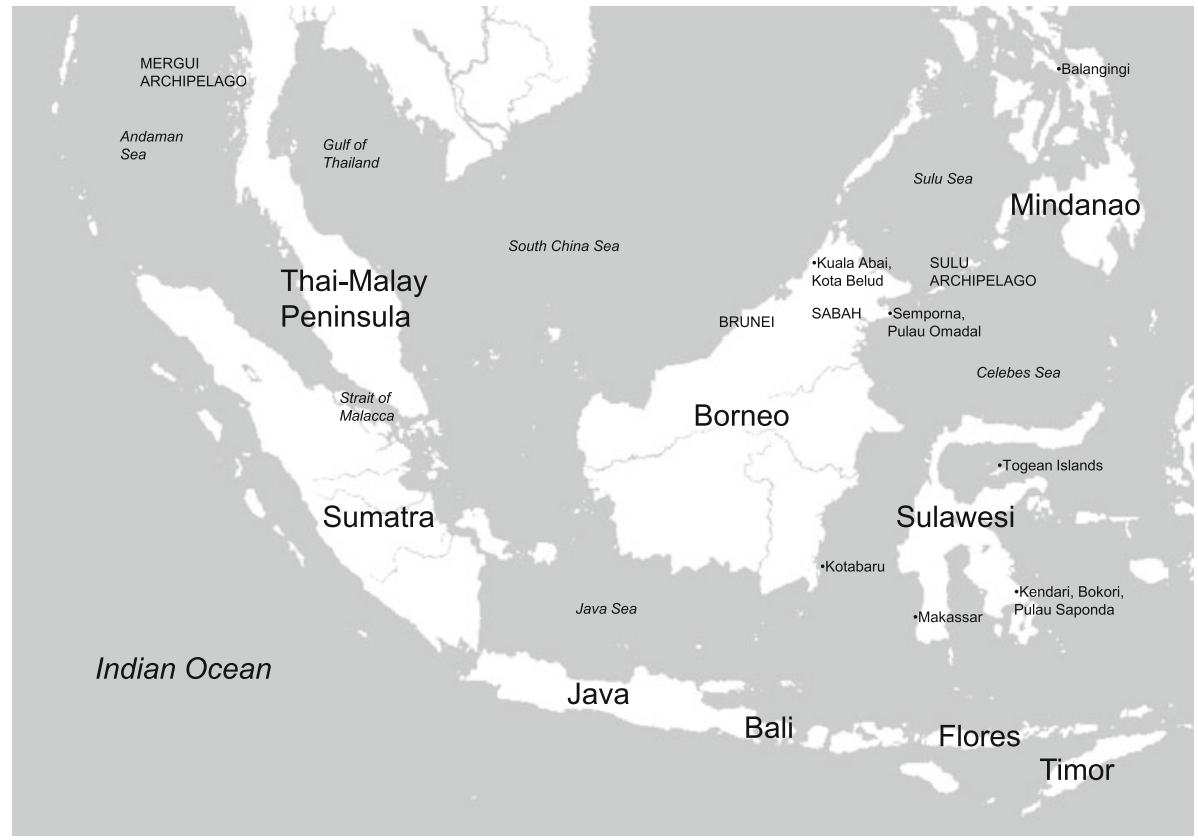

Fig. 1 Map of insular Southeast Asia

populations face challenges similar to those of indigenous peoples in general: poverty, social exclusion and external pressures from neighbouring communities and, indeed, from the wider world. Several contemporary relevant issues in Southeast Asia-such as globalisation, maritime transportation, piracy, and the complex relations between coastal and inland populations-have a long and increasingly well-understood history in this part of the world. Nevertheless, a lot of what happened on the seas and oceans has gone unnoticed by many conventional historians focusing on terrestrial events. In response, several scholars have started to focus on "seascapes" and other aquatic aspects (e.g. Boomgaard 2007). On this vein, the present study explores the maritime world of some of Southeast Asia's last entirely sea-oriented populations, focusing on their complicated and fragile relationship with more powerful entities, including local rulers, national governments and pirate groups. It examines their social hierarchies, notions of ethnicity and adaptations to societal change from a diachronic perspective. Special attention is given to the continuities and discontinuities between (pre-)colonial seafaring communities and today's modernised "sea people", in particular the pirates and maritime terrorists dominating the headlines of several Southeast Asian regions (Fig. 1).

According to the geographer Sopher (1965, p. ix), Southeast Asian nomadic boatdwelling communities numbered less than 20,000 souls at the time of his research. At the same time, they are found across an area stretching over more than 2,000 miles east-west and 1,600 miles north-south. Based on ethno-linguistic affiliation, the "boat dwelling" populations of Southeast Asia can be divided into three groups: (1) the Sama-Bajau, inhabiting parts of the Philippines, Borneo and eastern Indonesia, (2) the Moken, inhabiting the Mergui Archipelago and nearby coastal settlements belonging to Myanmar and Thailand, and (3) the Orang Laut, inhabiting the coasts and waters of the Thai-Malay 
Peninsula and Sumatra. ${ }^{1}$ Despite their considerable internal diversity and fragmentation, all groups are conventionally labelled under the umbrella terms "sea people" or "sea nomads", by Europeans and Southeast Asians alike. "Like the Rom, the gypsies of Europe," one author puts it, "they are often imagined to be colourful rogues who live outside society, ignoring its laws and conventions. Like most ethnic stereotypes, this vision is simplistic and inaccurate, with just enough truth in it to make it even more dangerous (Kortschak 2010, p. 102)".

The present study is largely based on the insights gained during my linguistic fieldwork among the maritime communities of southern Thailand, Sabah, Kalimantan and Sulawesi in March 2009, November and December 2009, July 2010 and March 2011. With little proficiency in the local vernaculars researched, I used Malay as a means of communication throughout this vast area. The limited amount of time I was able to spend in southern Thailand and the Strait of Malacca did not enable me to obtain a satisfactory, first-hand impression of respectively the Moken and the Orang Laut populations, so that I rely mostly on the work of others in comparing their situation with that of the Sama-Bajau communities, in particular those of Sabah (Kota Belud, Kuala Abai, Semporna, Pulau Omadal, Fig. 2), Kalimantan (Kotabaru) and Sulawesi (Kendari, Bokori, Pulau Saponda, Fig. 3), all of which I have visited personally as part of my fieldwork. Everywhere I went, their nomadic habits were discouraged by the national governments, resulting in large-scale, ongoing processes of semi-compulsory sedentarisation. Whereas many of the historically documented "sea people" in these regions lived entirely on boats and spent most of their lives on the sea, their present-day descendents reside almost exclusively in stilt-houses. This transformation seems to be complete in western Sabah, where the vast majority of formerly boat-dwelling communities have settled down in villages allocated to them by the government. Southern Thailand, Indonesia and some of Sabah's offshore islands still display some more or less traditional "boat villages". Unfortunately, such places are not uncommonly exploited by tour operators, so that, as one author puts it, "tourists in bikinis" can be seen "wandering around taking pictures of poor people" (Hope 2001, p. 145). In addition, Sabah's offshore islands house several stateless Sama-Bajau communities pigeonholed by the Malaysian government as undocumented Filipino immigrants. Despite the increasingly complex challenges of modernity, their illegal status leaves them with little choice but to continue their highly mobile lifestyle deprived of landownership, healthcare and education.

As mentioned previously, Southeast Asian historiography has, until recent times, predominantly focused on events that took place on the land, despite the fact that some of the earliest available textual sources on the region contain references to maritime communities. This study attempts to cast a new light on the actors and agents inhabiting Southeast Asia's seascapes of the past and the present, exploring who they are, what they have contributed to the region's history and how they continue to face the challenges of a life dependent on the sea in an increasingly terrestrially demarcated world. The first section explores the aquatic lifestyle of these communities, focusing on their culture, traditions and relations with outsiders. The second section highlights the Sama-Bajau communities as a case study and examines their notions of ethnicity and group membership. The third section elaborates on the historical relations between maritime communities and their

\footnotetext{
1 See Sopher (1965), Andaya (1984), Sather (1995) and Lapian and Kazufumi (1996) for more detailed elaborations.

2 Other terms include sea folk, sea hunters-and-gatherers, sea gypsies, people of the sea, aquatic populations, orang laut (Malay), suku sampan (Malay), orang suku laut (Malay), wong kambang (Javanese), turijene (Makassarese), chaaw lee (Thai) and hsa loun (Burmese) (cf. Sopher 1965, p. 104; Chou 2003, p. 2).
} 


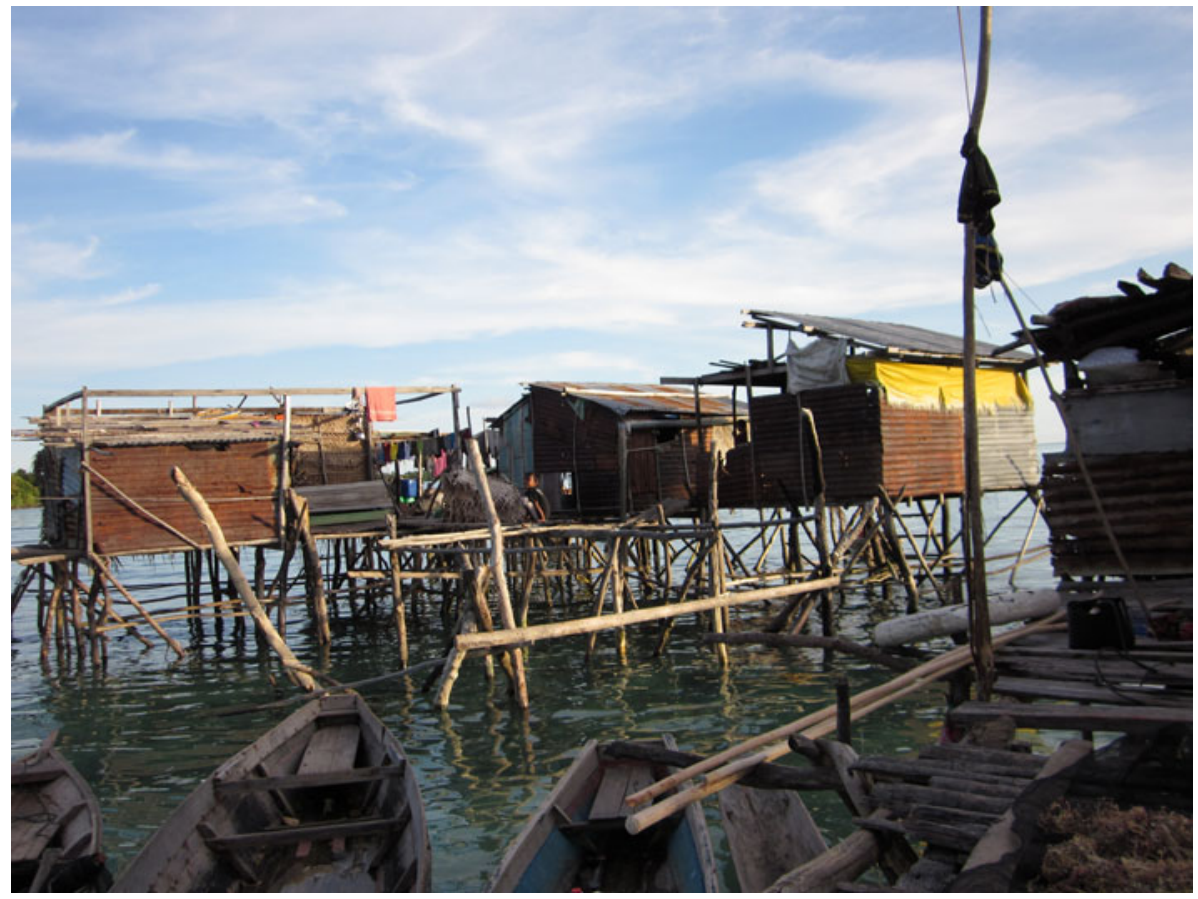

Fig. 2 A sea village in Pulau Omadal, Sabah, Malaysia

land-based overlords in pre- and early modern history. The last section focuses on piracy in an insular Southeast Asian context, putting into question the extent to which conventional definitions of this phenomenon sufficiently equip us with the analytical tools to understand the complexities and realities of Southeast Asia. In the "Conclusion" section, I will return to these issues and briefly address topics for future research.

\section{The boat-dwellers of Southeast Asia}

Maritime communities can be defined as societies with a dependence on the sea. They often inhabit littoral settlements or even houseboats. Typical professions include coastal and pelagic fishermen, pearl divers, boat-builders, traders in sea products, ship crew and occasionally-for want of a better term-"pirates". The reasons for their orientation towards the sea may differ; some communities inhabit small islands and rely on interinsular trade to sustain their livelihood, while others have resorted to a maritime lifestyle on account of unfavourable conditions in their homeland. The famous Phoenicians of Mediterranean antiquity form a well-known example of the second group. Some maritime communities rely on the sea for subsistence, some for trade, and some for both. In view of the fact that there is often an overlap between maritime, semi-maritime and seasonal maritime orientations, Yesner et al. (1980, p. 728) fine-tune this definition to people for whom "marine food forms the largest portion of the intake of calories or protein". Earlier, the renowned Dutch maritime anthropologist Prins (1965, p. 4) had listed the following cultural features prevalent amongst maritime societies: 


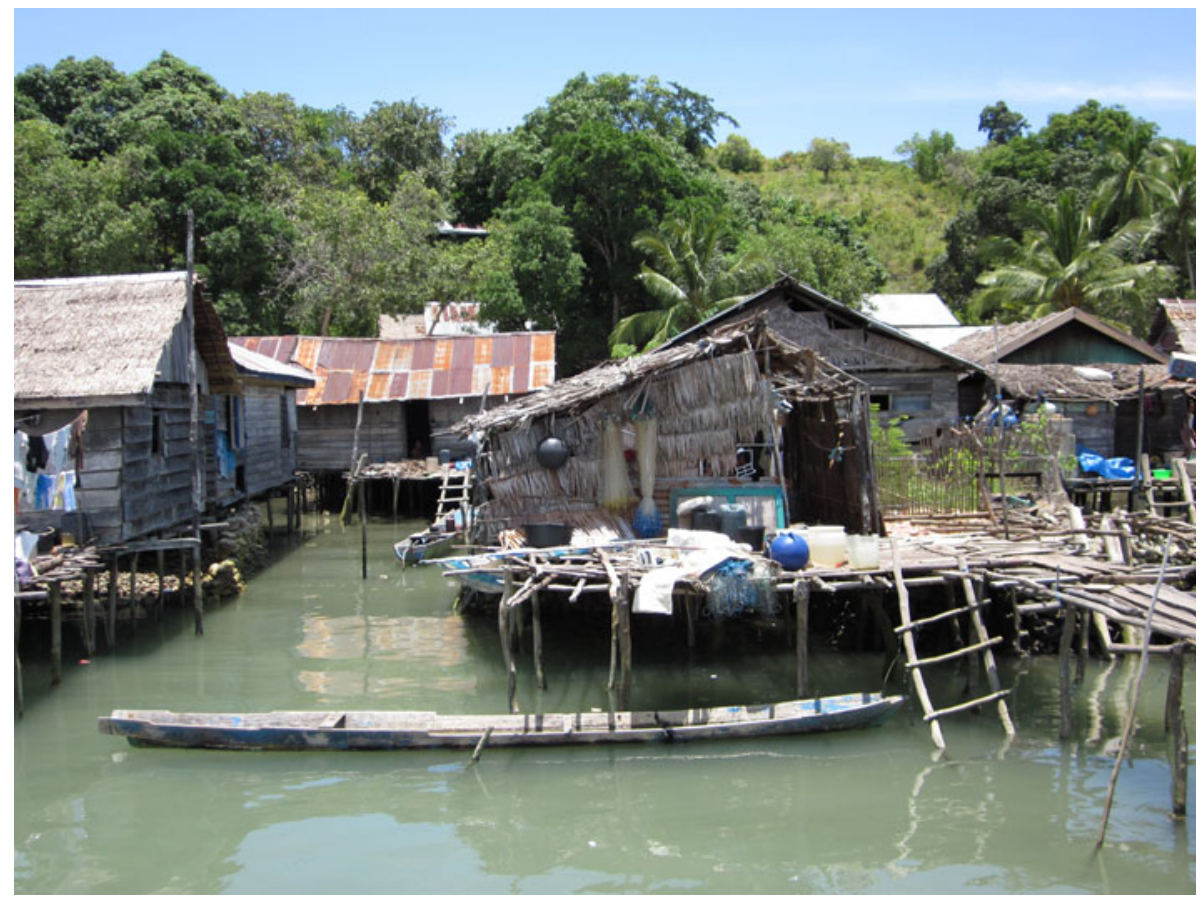

Fig. 3 Bokori, a Sama-Bajau village in Southeast Sulawesi, Indonesia

"The occurrence of maritime proverbs and their frequent (or frequency of) use; children playing with toy-boats; men building ships' models in their leisure hours; the integration of sea and ship into the make-up of functionally non-maritime institutions (votif [sic!] offerings, initiation, mortuary ritual, etc.); the (degree of) elaboration of myths concerning the sea; the occurrence of maritime patron-saints (like our St. Nicholas); the spending of leisure hours near the waterfront, crowds gathering at launchings, arrivals and departures of ships; the attitudes toward fish, and so on, and so forth."

The people discussed in this article can be classified as nomadic or semi-sedentary huntingand-gathering communities who exploit the sea as a source of nutrition and other desirable materials. They are different from sedentary maritime-oriented communities, such as the Buginese from southern Sulawesi, the coastal populations of Zanzibar, or, for that matter, the historical Vikings, as these groups have a homeland and maritime voyages are almost exclusively undertaken by men. The communities in this study, on the other hand, typically spend their entire life afloat and ashore. As a result of their (semi-)nomadic lifestyle, such groups exhibit a very rudimentary material culture. Even among today's boat- and shoredwelling communities of Southeast Asia, the desire for material wealth is often rejected as a cultural reflex. Consequently, the archaeological record displays very few traces of "sea people", obscuring their prehistoric significance or even presence.

Most seas in insular Southeast Asia have the characteristics of closed seas. In several areas, notably the Sumatran east coast, mangrove swamps never allowed for permanent residence, yet provided valuable resources for nomadic communities (Andaya 2008, p. 61). Despite this area's ancient seafaring tradition (cf. Lape et al. 2007, p. 240; Barker and 
Rabett 2009), many communities gradually lost their maritime lifestyles and ultimately became land-oriented. Moreover, some communities still inhabited coastal areas but became "thalassophobic", i.e. developed an avoidance towards the sea (Lapian 1987, pp. 142, 143). The names of these communities often contain clues regarding their maritime or inland orientation. Compare, for example, the ethnonyms Toraja 'people of the uplands' and Tondano 'water people', two communities inhabiting the same Indonesian island (Sulawesi). As regards Southeast Asia's traditional maritime-oriented societies, several general observations can be made. First of all, they are dependent on the availability of sea produce. For security, safety and in order not to overexploit their natural resources, they usually move in small clusters consisting of 10-20 houseboats, each boat housing one family. One community of sea people generally consists of 50-150 individuals (cf. Lamster 1937, pp. 267, 270).

In the foreword of his pioneering study on Southeast Asian maritime communities in the textual record, Sopher (1965) underlines the importance of these non-literate and highly mobile groups of people for the seaborne diffusion of various cultural aspects. However, as these people were analphabetic, all the historical information we have about them has been filtered through the lens of others, including writers, government officials and documentary makers. In a terra firma-centric society (including practically all modern nation states), moreover, fishermen and others relying on the sea for their livelihood tend to be poor and not highly esteemed (Young 2004, p. 70). In Southeast Asia, too, land-based people generally look down on boat-dwellers and describe them as primitive, wild and uncivilised, or, in the words of Hope (2001, p. 140), "obstinate to the point of stupidity, dirty to the point of contagion and backward to the point of invalidity". The fact that some of these communities have not adopted Islam or Buddhism also plays a role in these low estimations, as a religious leader is often perceived as the head of the hierarchy in Southeast Asian cosmology. On the other hand, some communities are, to a certain extent, respected and feared for their knowledge of natural products and presumed possession of magic skills and mythical feats, including the ability to stay under water for half an hour, live for days without fresh water, drink brackish water without injury and breathe through gills (Lamster 1937, p. 269; Sopher 1965, pp. 122, 130, 152; Lapian 1987, pp. 144, 145).

These communities are almost exclusively involved in occupations directly related to life on the sea, such as fishermen, boat-builders, traders in sea products and personnel on private ships. More recently, a few groups have engaged in tourism on certain islands off Sabah, the Togean Islands of Sulawesi, southern Thailand and other regions. There complete dependence on the sea has been no different in the past. Since the earliest available descriptions, the economy of Southeast Asian maritime hunter-gatherers has been based on resources from the sea and trade with sedentary communities. Even in modern times, products from the sea-such as several types of fish and molluscs, seaweeds, crustaceans, sea urchins and jellyfish-form the most important nutritional component in the diet of maritime communities across Southeast Asia. In general, the most valuable sea or littoral products in this part of the world are fresh and dried fish, tortoise eggs, edible swallows' nests, salt, seaweed, precious shells, pearls, nacre or motherof-pearl (Malay: gewang), a special type of black coral (akar bahar) from which bracelets are made, sea cucumber (tripang) and tortoise shell (karet), which are often traded for rice, wood, bamboo and other products (Lamster 1937, p. 268; Sopher 1965, pp. 60, 61; Pallesen 1977, p. 19; Boomgaard 2007, p. 9). Since historical times, the major portion of these trade commodities was intended for the Chinese market. Given their occurrence, but certainly not abundance, in the South Chinese waters, many of these products must have been known to the Chinese of antiquity (Sopher 1965, p. 248). 
Despite their frequent interaction with people with a more sophisticated material culture, many groups of maritime hunter-gatherers never felt the need to incorporate foreign cultural practices from land-based communities, such as agriculture, organised religion, more elaborate fishing techniques, and even advanced boat types. After all, they could easily move to locations with less competition from better organised fishermen (Sopher 1965, pp. 48, 144). In contrast with land-based communities, sea people also had limited access to natural resources and were often dependent on logs drifting downstream for the construction of boats and stilt houses (Martenot 1981, p. 184). This might help us to understand why, in spite of their maritime lifestyle, the Moken and Orang Laut are often confined to the most primitive types of watercraft (Sopher 1965, pp. 197, 198, 200, 201), whereas the Sama-Bajau communities generally employ the same types of boats as the land-based communities around them (Haddon 1920, p. 115; Sopher 1965, p. 132; Martenot 1981, p. 184). Another reason for their reluctance to adopt technological innovations from the land may be that these communities consciously avoid sedentary lifestyles, as doing so would eventually result in assimilation into existing land-based communities. Instead, their indigenous way of life is perceived to accentuate both freedom and a feeling of a unique identity (Andaya 2008, pp. 199, 200). Thus, many prefer their traditional lifestyle even when given the option to settle down. The emphatic, voluntarily rejection of the land and everything it yields is exemplified by the strict taboos among various clans on the consumption of meat and eggs from any land animal (Sather 1997, p. 96). On the same vein, various people have personally assured me that they feel dizzy in the absence of sea water and get physically ill after venturing too deep inland or driving a (non-aquatic) vehicle.

\section{Identities of placelessness and displacedness}

There are strong indications that traditional concepts of ethnicity in small-scale Southeast Asian communities were (and are) far from rigid. After all, a relatively high degree of interaction between different communities often leads to exogamy and multilingualism, both of which are very common among the Orang Laut and Sama-Bajau communities (Sather 1997, p. 11; Chou 2003, p. 10). In general, strict notions of ethnicity in Southeast Asia were presumably adopted from outside. Illustratively, we see that the Sanskrit word vamśa, denoting a line of a pedigree or genealogy, has been borrowed into Khmer as pəəysa?, Thai wonysăa, Lao phónsă:, Burmese wun tha, Malay bangsa and Tagalog bansa, all referring to notions of belonging to a single ethnicity, nation or lineage. According to Andaya (2008, pp. 4-7), the emergence of Malay kingdoms was a further stimulus for the formation of clearly demarcated ethnic identities, which can be re-formed to include and exclude others. Before this process of politicisation of ethnic identities-evidently a result of increased economic competition and the subsequent desire of people "to define and redefine themselves to promote their individual and groups interests" (Andaya 2008, p. 11)—notions of identity in Southeast Asia may have been much less rigid than they are now. ${ }^{3}$

Let us now single out one group of ethno-linguistically related people, the Sama-Bajau, and explore their notions of ethnic identity in more detail. Most, but not all, of these communities refer to themselves using the autonym "Sama", whereas outsiders tend to use the

\footnotetext{
3 Occasionally, one may argue that ethnicities in Southeast Asia continue to be fluid to date. Illustratively, Malaysia is presently houses people from South Asian, Thai, Eurasian and other ethnic backgrounds who identify themselves as "children of the soil" (bumiputera), as doing so provides them with numerous advantages and privileges.
} 
exonym "Bajau" (Lapian and Kazufumi 1996, pp. 46, 48; Boutin \& Soderberg 2009). Although there is some evidence for their historical presence in the waters of Sumatra and the Strait of Malacca (Sopher 1965, pp. 161, 162; Lapian and Kazufumi 1996, p. 49), SamaBajau communities are nowadays predominantly found around Borneo, Sulawesi, the southern Philippines and eastern Indonesia. Their direct ancestors presumably hailed from the southern Philippines (cf. Pallesen 1977), although several Sama-Bajau groups claim descent from the Malay kingdom Johor in the Strait of Malacca. Such claims must be contextualised in a setting of semi-mythological lineages from and patron-client relations with ruling dynasties, on which I will elaborate in the next section. Ultimately, linguistic data points to the mainland of Borneo as the homeland of the Sama-Bajau communities, prior to their migrations to the Philippines and elsewhere (Blust 2006). The scenario of an inland Bornean origin appears to be supported by historical accounts (Nicholl 1972, p. 85; Harrisson 1976). Indeed, the ancestors of the Sama-Bajau were not entirely focused on the sea. Pallesen $(1977$, pp. 117, 225) demonstrates that they were oriented both to the sea and to the land. This dual orientation continues into the present. Sama-Bajau in central Sulu, for example, distinguish three demographic niches: (1) the sama dilaut or 'Ocean Sama', who are fully oriented towards the sea and live on boats or stilt-houses only reachable by boats, (2) the sama lipid or 'Littoral Sama', who are economically oriented towards the sea and live on shallow waters or on shore in houses connected by elevated walkways, and (3) pangutaran sama, who have a basic orientation towards the sea, but are also effectively farmers (ibid. 157). Similar distinctions are made among other Sama-Bajau groups (e.g. Peralta 1995, p. 1).

During my fieldwork in Sabah, I had the opportunity to inquire about people's perceptions on the Sama-Bajau identity. One coastal village, Kuala Abai, is home to two distinct SamaBajau clans of different ethno-linguistic affiliation. The original inhabitants are West Coast Bajau, a community that has largely switched to agriculture, whereas a minority of newcomers consists of maritime-oriented Bajau Ubian from the Sulu Archipelago. During the village's history of multi-ethnic cohabitation, the incorporation of the latter group into the former took place in a remarkably smooth way. Elsewhere in the region, too, we see that Sama-Bajau people from Malaysia can easily blend in with their kinsmen from Indonesia or the Philippines and vice versa. To my question what it takes to become a Sama-Bajau, one consultant answered that one needs to be from the region, take over the Sama-Bajau lifestyle and adopt Islam. The importance of religion among the Sama-Bajau, however, could be of relatively recent significance, resulting from the desire to delimit themselves politically from Sabah's Christianised inland populations (Saat 2008).

This brings us to our next problem: Who is regarded a community member and who is not? How can we distinguish an ethnic identity from a demographic niche? Is it possible for people to move in an out of a maritime population by simply changing lifestyle (cf. Astuti 1995; Mack 2007, p. 10)? Given the taboos on marriage between family members, nomadic seafarers in Southeast Asia were distinctly exogamous, making their societies quite dynamic and open to external intermarriage (Sopher 1965, p. 273; Lapian and Kazufumi 1996, p. 50). In an account on Sama-Bajau communities, a Dutch author commented that they were "mostly Chinese with long beards, Javanese with thinly plucked beards and moustaches, Makassarese and the likes with filed teeth, and several others, such as Balinese, Malays etc." 4 This is probably an exaggeration; while the Sama-Bajau communities were not averse to accepting outsiders into their community, their lifestyle

\footnotetext{
${ }^{4}$ My translation; the original Dutch text is quoted from Lapian (1987, pp. 155-156): “[...]sijn meest Chinesen, met g'ijlde lange baarden, Javanen met kale uijtgepluckte baard en knevel, Macassaren en andere met gevijlde tanden, en verscheijde kennelijcke andere slagh van Baliers, Maleijers \&ca[...]".
} 
was never dominated by foreign elements. When a man of, let's say, land-bound Sulawesi origin married into a Sama-Bajau family, he would lose his previous identity and become a Sama-Bajau (Sopher 1965, pp. 149, 150; Zacot 1978; Lapian and Kazufumi 1996, p. 50). Similarly, there are some accounts of Buginese sailors who ended up in Sumatra, encountered Orang Laut populations, took over their lifestyle and thus effectively "switched identity" (Schot 1884). On the other hand, the decision to settle down, marry into land-based communities and adopt their manners-including their clothing style and religious practices-inevitably resulted into losing one's Sama-Bajau identity and assimilating into the mainstream (Matthes 1872, p. 17; Lamster 1937, p. 267; Sopher 1965, pp. 149, 150, 182). Social ostracism is another way to lose the Sama-Bajau identity. Illustratively, several consultants have assured me that somebody involved in drug abuse is no longer regarded as a group-member (dianggap bukan anak lagi).

Several issues plague the contemporary "sea people" across Southeast Asia. Foremost, their level of education is markedly lower than that of their land-dwelling neighbours. In part, this is because their villages tend to be extremely remote and teachers from outside are often reluctant to settle there permanently. There is also an important cultural factor; while these small-scale fishermen may take pride in a wide array of maritime skills, they do not always prioritise higher education (arguably, the inability of many cosmopolitan landdwellers to swim, fish or propel a boat can be explained along similar lines). In addition to their irregular fishing hours, widespread racial and cultural discrimination causes many children of "sea people" to drop out of school at an early age, if they go to school at all (cf. Chou 2010, p. 7; Kortschak 2010, p. 106). Nevertheless, it would be quite wrong to state that there is a cultural aversion to knowledge-gathering beyond the essential maritime skills. Everywhere I went, children are encouraged to learn how to read and write in order not to be fooled (tidak dibodohi) by malignant outsiders. In addition, "sea people" possess an impressive linguistic repertoire. Illustratively, it is very common for someone in the multiethnic town of Kotabaru, South Kalimantan, to be fluent in one or two Sama-Bajau dialects, Banjar Malay, standard Indonesian and some of the languages of their neighbours, such as Mandarese, Javanese or Buginese. Similarly, in Sabah I have met people conversant in local Sama-Bajau dialects, Sama-Bajau dialects from the Philippines, Sabah Malay, standard Malay and such regional languages as Tausug or Kadazandusun.

Despite their linguistic proficiency, many "sea people" remain shy in dealing with terrestrial communities. While almost all Sama-Bajau communities have adopted Islam, religion-or the perceived lack thereof-remains a stumbling block for the relations between the nominally Islamic Orang Laut communities and their direct neighbours, in particular the more devout land-based Malays (cf. Chou 2010, pp. 105ff., 116). Furthermore, strong cultural prejudices against a maritime, nomadic lifestyle are found throughout contemporary Southeast Asia. Sama-Bajau fishermen are often accused of being involved in illegal maritime activities, such as smuggling, pollution and destroying the environment. The truth is far more complex; often they see few alternatives to feed their families. Their non-sedentary background disqualifies them from obtaining land certificates, so that many find themselves trapped in a vicious circle: they do not have the collateral to obtain loans and therefore lack the means to raise capital and improve their situation. Their situation is further aggravated by the ruthless overfishing of their seas by better-equipped fishing operators and by the poor quality of near-shore water due to logging and mining operations on land. This combination of factors makes it increasingly difficult, if not impossible, for them to rely on traditional fishing methods. As a result, some small-scale fishermen resort to fish-bombing and cyanide poisoning, both highly dangerous and detrimental to the coral reefs that form the backbone of their livelihood. The adoption of modern technology has 
introduced a new set of problems. Over the last decades, many fishermen have died due to accident-prone fish bombs and low-quality diving equipment, increasing the often poorly understood risk of decompression illness. The situation is most dire for the inhabitants of the offshore islands around Sabah, who lack the Malaysian citizenship and are regarded as illegal migrants from the Philippines. In reality, the Malaysian-Philippine border belies a much older cultural interaction sphere, with many Sama-Bajau clans traditionally moving back and forth between the regions. In effect, the unregistered Sama-Bajau people of Sabah lack birth certificates and are deprived of basic human rights, including healthcare and education, further exacerbating their vicious circle of poverty and underdevelopment.

On the brighter side, Indonesia, Malaysia and the Philippines all display an increasing number of successful Sama-Bajau politicians, businessmen and artists able to overcome these and other obstacles, who serve as powerful role models for their communities. In response to the gloomy prospects of rigid adherence to a maritime lifestyle, Western Sabah and parts of Sulawesi-due to government support programmes-witnessed the transformation of former fishermen into successful farmers within a few generations. Others have attempted to face the challenges of modernity without abandoning entirely their maritime lifestyle. Several Sama-Bajau villages in southeast Sulawesi have seen the emergence of stilt-house medical health centres (puskesmas) and elementary schools as integral and essential parts of their village, while specialised academic programmes that bring together the traditional knowledge of Sama-Bajau fishermen and the latest developments in modern fisheries management have been developed over the past few years (Haris Ibrahim, pers. comm.). Collaboration and dialogue between community leaders and local governments have also improved greatly over the years, yielding poverty alleviation programmes set up especially for Sama-Bajau communities (Rasyid Bafadal, personal communication). In general, the situation in Indonesia and Malaysia is slowly improving. It should be added, however, that many communities in Sabah are unable to benefit from any of these developments due to the aforementioned issue of questionable citizenship.

\section{Power relations and the role of the sea}

Many origins myths of Southeast Asian "sea people" involve a story in which their ancestors were cursed and forced to live on boats without a religion, only suitable to serve under the patronage of others (Sather 1997, p. 20). Such patron-client relationships between established political entities and nomadic communities can be observed throughout Southeast Asian history. Despite the marginalised position of "sea people" today, their roles in the societies of insular Southeast Asia appear to have been considerably greater and more varied in the past. As mentioned in the previous section, the economy of present-day maritime communities in Southeast Asia often depends on trade with others. The same observation was made by early European authors (Sather 1997, p. 36) and the situation was probably no different in pre-modern times. Imported beads and ceramics dated to the beginning of the Common Era have been found on offshore islands off the Thai-Malay Peninsula, underlining the important historical function of maritime communities in interethnic trade (Bulbeck 2004; Andaya 2008, pp. 192, 193). Similar dynamics prevailed in other times and places; the establishment of Kendari as an important commercial nexus from the 19th-century onwards was facilitated by the strong ties between Buginese royalty (to wit, prince Arung Baku) and local, well-connected SamaBajau seafarers (Andaya 1984, p. 41). Across pre- and early modern Southeast Asia, aquatic populations often served as respected subjects to land-based rulers. The first known 
instance of these mutually beneficial power relations transpires from the role of "sea people" in the famous seventh to 13th-century Sumatran kingdom of Śrivijaya, in which several Orang Laut clans had different territories and responsibilities to the king, including assistance in trade and warfare (Chou 2003, p. 18; Andaya 2008, pp. 177, 178). The better documented epoch of the kingdom of Johor displays similar power relations (Andaya 1975).

Our understanding of aquatic elements in Southeast Asia's past is by no means a construct deduced exclusively from the insights of historians and archaeologists. The first scholar to explore the historical importance of the region's nomadic maritime communities from a linguistic point of view is Waruno Mahdi (2009), who argues that several loanwords dispersed both into and out of insular Southeast Asia were transmitted by sea-dwelling communities speaking vernaculars of the distantly related Moken and Orang Laut (Urak Lawoi') dialect chains. His findings are somewhat surprising in view of the fact that the Moken are usually believed to have played a rather marginal role in Southeast Asian trade and commerce (Ivanoff 1989; Sather 1997, pp. 323, 324; Andaya 2008, p. 176). Early 20th century ethnographic studies depict them as extremely timid, immediately fleeing at the sight of strangers (cf. Sopher 1965, p. 71). However, this situation is presumably the result of relatively recent suppression by Malay pirates and Burmese invading forces. Epigraphic evidence suggests that the Moken were once fierce pirates themselves (Luce 1965, pp. 145-147). In addition, a small set of nautical terms seems to have reached the Southeast Asian mainland through Moken-speaking people (Hoogervorst 2012). These inferences suggest that the role of especially the Moken populations in the history of Southeast Asia was more important than previously appreciated.

Let us now focus on the historical relations of the Orang Laut (Malay for 'sea people'), as the maritime communities inhabiting the waters of the Thai-Malay Peninsula and Sumatra are generally called. Like the Moken, Orang Laut are occasionally described as having "negrito" features, such as dark skin, curly hair and a short statue, although the degree of admixture, if any, is probably very slight (Sopher 1965, pp. 112, 164-168). The Orang Laut communities consist of various different clans, who were occasionally at war with each other. Given their distribution in clusters, there was never a single Orang Laut leader (Andaya 2008, p. 184). As mentioned before, these people were highly mobile, probably in order not to overexploit their maritime resources. Their nomadic habits and ways of conceptualising space, however, were bound to certain rules. They did generally not venture beyond their own "maritory", i.e. their specific territory of maritime exploitation (ibid. 180). Although land-Malays tend to view the Orang Laut as a homogenous group, the cultural differences from group to group are considerable even within the boundaries of a single Indonesian province (Sopher 1965, pp. 92-97; Chou 2003, p. 10). Despite some early studies (Kähler 1960; Hogan 1988), not much is known about their numerous dialects, such as Bahasa Galang, Bahasa Duano and Urak Lawoi'. These vernaculars are all closely related to Malay, albeit not always mutually understandable. Another similarity with the Moken is the depiction of the Orang Laut as shy and elusive people in early 20th century ethnographies (Andaya 2008, p. 187). This stereotype requires a fair bit of adjusting. Even nowadays, many land-Malays regard the Orang Laut as dangerous and proficient in black magic (Chou 2003, p. 2). These perceptions seem to be a continuation of their past as fearsome pirates, on which I will expand below. In any case, the best approach seems to be to regard each group as having distinct characteristics, subject to change over time (Lapian 1987, p. 49).

The power networks described above urge us to examine what the nomadic maritime communities gained from their terrestrial patrons in return for their support in establishing 
the latter's maritime dominance, assistance in warfare, efforts to maintain security in certain sea lanes, collection of valuable sea produce and promotion of international trade. First of all, they had the assurance of a market for their goods and, if so required, increased access to foreign goods under the protection of land-based overlords (Andaya 2008, pp. 173, 188). Not only were they rewarded economically for their services, they also enjoyed the privileges of obtaining water and firewood, anchoring their boats and building pilehouses within the borders of their overlords (Pallesen 1977, pp. 20, 21; Lapian 1987, p. 36). "Privileges" of the latter type-in reality often extortion of protection money-remain common in parts of Sabah, where several Sama-Bajau communities inhabit territories under patronage of Tausug leaders (Helen Brunt, pers.comm.). However, around the Strait of Malacca, where Orang Laut communities were able to successfully control their littoral habitat without any interference of territorial overlords, these dynamics do not suffice to explain why aquatic people sought foreign patronage. One of the most important factors might have been social status. As a part of land-based kingdoms, the otherwise feared and marginalised communities could obtain legitimisation for their lifestyle and even honorary titles within the royal families through marriage bonds (Andaya 2008, pp. 173, 188, 192; Saat 2008, pp. 65, 66). Nevertheless, the relations between land-based kings and their vassals, maritime or other, were often of a very fragile character. In Southeast Asian epigraphy, supernatural punishment is an often reoccurring theme to punish the disloyal. An oft-cited example in Old Malay epigraphy is the 686 AD dated Kota Kapur inscription, discovered on the island of Bangka and connected to the Śrīvijaya Empire, which contains a prelude in an unidentified language. Aichele (1954, pp. 113, 114) suggests that the prelude is a malediction formula against anti-Śrīvijaya rebels in their own language, intended to kill whoever committed crimes against the divine ruler, although the lines are yet to be satisfactorily translated (cf. Ferrand 1932, p. 28; Obdeijn 1943; Damais 1968; Dahl 1991). Political power structures based on the presumed supernatural powers of leaders persisted into the colonial period, as is evidenced by comparable accounts on the Batak clans in Sumatra (Andaya 2008, p. 167). In the case of the various nomadic communities serving Śrīvijaya, however, military operations towards recalcitrant subjects would have been limited, given that the latter could simply disappear into the impenetrable forests or offshore islands.

In Borneo and the southern Philippines, we can observe power relations similar to those in the Strait of Malacca. This strategic region, connecting Southeast Asia with China, became the playground of competing ethnicities involved in maritime raiding: the Maguindanao, Maranao, Tausug, Ilanun, Sama-Bajau and, later, Europeans. In the 16th-century, the Malay Sultan of Brunei claimed proprietary rights over all non-sedentary communities of his territory as his subjects, from whom he was entitled to render assistance in times of war or rebellion (Pallesen 1977, p. 20; Hamzah 1995, p. 14). According to Spanish documents, these communities developed into coastguards to safeguard Brunei's commercial activities (Nicholl 1977). After the decline of the Brunei Sultanate, SamaBajau communities, who were traditionally at the bottom of the hierarchy, placed themselves under the protection of other powerful entities. As such, they have been documented as slave-raiders under Tausug overlords in the Sulu Archipelago, as tripang collectors sailing as far as northern Australia under Buginese patronage and even as sailors under the flag of Holland (Vosmaer 1839; Sopher 1965, pp. 131, 144, 145; Sather 1997, pp. 14, 40). While the different ethnicities of the Sulu region often joint forces, their relationship was always one of hierarchical nature, with Tausug patrons (datu) at the top, directly followed by squadrons of Ilanun marauders (panglima) and finally by lower crewmembers recruited from Sama-Bajau and other impoverished communities (Campo 2003, pp. 166, 167, 172; 
Warren 2002, p. 208ff., 2007, pp. 131, 132). These power structures explain how it was possible for entire clans to undergo a relatively quick transformation from peaceful fishermen into professional pirates under the compulsory patronage of local rulers, as had been the case with the Sama-Bajau community of Balangingi Island (Warren 2002, p. 147ff.). It also explains why marginalised fishermen continue to be the most important labour pool for piracy in present times.

While the emergence of steam navigation and military improvements had reshaped the Southeast Asian seascapes and interethnic power relations in the favour of the western colonial nations, the abovementioned social dynamics and hierarchical patterns help us understand contemporary processes in the region. Theft, exploitation and violence by Tausug dominated pirate groups is still very common among depauperate Sama-Bajau fishermen (Eklöf 2006, p. 41ff.). Although the "well-organised, financed and ruthless" Ilanun pirates that plagued the Sulu zone from the late 18th century (Warren 2007, p. 126) might not display direct continuities to modern sea crime in this region, their relatively easy incorporation into the dominant power structures on the Southeast Asian waters is a recurring trend. On the other hand, the existence of national borders, in particular the maritime border between Malaysia and the Philippines, also brought new lucrative opportunities for maritime crime. Price differences between these countries led to the establishment of various smuggling networks, in which some well-organised Tausug clans continue to outwit the Malaysian navy by fleeing across the Philippine border after they are detected (Tokoro 2010, p. 284).

\section{Recontextualising piracy in Southeast Asia}

This brings us to piracy: a key element in the aquatic past and present of Southeast Asia, presumably from the beginning of lucrative maritime trade. In general, the main areas in which piracy existed historically and continues to exist today are the Strait of Malacca, the Gulf of Thailand, the South China Sea and the Sulu Archipelago. This section explores the cultural dynamics of the activities now universally condemned and labelled under the blanket term "piracy" in an attempt to increase our understanding of both historical and contemporary developments in maritime crime. In doing so, the focus is predominantly on Southeast Asian pirates, while acknowledging that the habit was also frequently carried out by Chinese and, later, European outlaws. In contrast to South Asia, the Middle East and the Mediterranean (cf. Gupta 2007; Sheriff 2010, pp. 8-10), written sources on Southeast Asian piracy are rather limited. Southeast Asian pirates are briefly mentioned in some of the earliest textual accounts on the region (cf. Maspéro 1928, pp. 68-74; Wolters 1967, p. 152; Young 2005, pp. 7, 8), but these accounts, written by fear-stricken visitors, leave the exact ways in which these pirates operated beyond our realm of knowledge.

To better understand the local contexts of piracy, we may point out that the activity of maritime raiding — known as mangayaw — was traditionally incorporated in the laws of many Southeast Asian societies in times of tribal warfare (Young 2004, p. 34). Moreover, for people used to taking whatever they need from the sea, piracy has been regarded as a logical and culturally sanctioned extension of the economy of nomadic hunter-gatherers (e.g. Ormerod 1978, p. 69). "Like the epic cattle raids of Ulysses or Irish folk hero $\mathrm{Cu}$ Chulainn," one author puts it, "mangayaw was the esteemed occupation of the able-bodied male who could afford it" (Scott 1980, p. 27). As a result, organised maritime raiding had become entrenched in the pre-modern societies of insular Southeast Asia as a means to enhance the power and status of rulers (Campo 2003, pp. 169, 170), as was the case with 
slave trade and debt bondage. Indeed, activities such as maritime robbery, captivity in war and slave-raiding formed the backbone of many coastal polities in the region (Raffles 1978, p. 233; Warren 2007, p. 127). In the Malay World and the Philippines, people who wereor would have been-labelled as "pirates" by colonial powers were often venerated as local heroes (Young 2004, pp. 23, 24; Eklöf 2006, p. 39). In the Malay literature, too, piratical cruises are referred to with an unmistakable glint of pride (cf. Raffles 1978, p. 232). As a result of these dynamics, entire communities had developed into highly specialised maritime predators in this part of the world..$^{5}$ Oft-cited examples of such communities are the so-called Moros, an umbrella term for different sea-oriented Muslim communities in the Philippines, such as the Tausug, Ilanun, Balangingi and Mangindanao.

As is now clear, indigenous Southeast Asian concepts of maritime raiding show a fair degree of dissonance with the "romantic anti-colonial aura [...] akin to peasant unrest, social banditry, and the Luddites" that piracy had appropriated in the western literature (Boomgaard 2007, p. 8). On the other hand, the habit formed a severe blot on the escutcheon of the Dutch, British and Spanish colonial rulers, none of which had succeeded in eradicating piracy —often supported by local kings-from this region (cf. Kniphorst 1875, pp. 19-21, 41-43). In fact, it may be argued that only the severe punitive actions of the Ming Dynasty admiral Zheng He were able to temporarily crack down piracy in the region, only to resurface after the latter's influence in the region declined. Moreover, the markets of global magnitude opened up and dominated by European imperialists have evidently augmented piracy (Bijdrage 1858, p. 88; Rutter 1986, pp. 26-28; Eklöf 2006, pp. 43, 44; Warren 2007, pp. 125-126). A 19th-century Dutch report describes how pirates successfully camouflage their boats with branches and leafs to escape from the sight of modern war boats (Kniphorst 1875, p. 27). Given that many communities also gather seaproducts seasonally, it must have been extremely difficult for the authorities to distinguish peaceful groups from raiding parties, something that continues to be the case to date. Nevertheless, one can observe general trends in the frequency of maritime violence in Southeast Asia. Through history, piracy often increased after the disintegration of large states, such as Śrīvijaya, Malacca, Brunei and the Sulu Sultanate, followed by the absence of a strong state authority and guarantee of livelihood through regular trade (Tarling 1963, p. 119; Wright 1979-1980, p. 210; Young 2004, p. 47). During these piracy booms, pirates temporarily were the state.

In order to better understand the social processes at play on the Southeast Asian seas, we need to also assess the aptness of the term "piracy". The term "pirates" is generally used for people who assert violence on sea for their own benefit, rather than in the name of a nation (Lapian 1987, pp. 214, 215). While piracy in a European sense was often-but not always - carried out by individuals, we have seen that Southeast Asia is home to entire communities dedicated to this activity. In the strict sense of the word, pirates victimise all shipping and are outlawed by their own officialdom. People operating with a special license from a recognised political entity were known as "privateers" or, in the Mediterranean context, "corsairs". They were allowed and even encouraged by their overlords to attack enemy ships. People operating without such explicit authorisation were called "freebooters" (e.g. Mahdi 1999, pp. 178, 179, 2008, p. 133 fn. 69). Obviously, there is a thin line between a pirate, a freebooter and a privateer, as the legitimacy of their actions is often in the eye of the beholder. Illustratively, the predatory activities by Orang Laut

\footnotetext{
5 Mahdi (2008, p. 133, fn. 69) proposes to label those communities who, as an ethnicity-specific custom, victimise any shipping and coastal settlement as "sea rovers". This term would include the abovementioned Southeast Asian communities, but also the historical Vikings.
} 
communities were often described as piracy in colonial Dutch sources, whereas the Malay sultans regarded them as a laudable effort to control their sea-lanes (Andaya 2008, p. 182). A mid-19th century Dutch rapport on piracy in the East Indies highlights that not all pirates in this region are simply criminals, nor fisherman and traders that occasionally resort to pillaging and plundering (Bijdrage 1858, p. 77). Instead, violence at sea "has been termed a legitimate form of Malayu statecraft when it occurs as part of the patron-client arrangement, but as piracy without such legitimisation" (Andaya 2008, p. 190). Many "pirates" belonged to societies in which every wealthy or powerful member is-financially, politically or militarily - engaged in maritime raiding.

In an attempt to understand these demographics from an indigenous Southeast Asian perspective, the Indonesian historian Adrian Bernard Lapian (1987) proposes a distinction into three groups of people who inhabited Southeast Asia's seascapes: (1) the raja laut or 'sea kings', who belong to a local kingdom and attack enemy ships to establish the maritime dominance of that kingdom, (2) the bajak laut or 'sea raiders', who do not belong to any local or colonial officialdom, attack all ships and gain additional income from slaveraiding, and (3) the orang laut or 'sea people', i.e. the Sama-Bajau, Moken and "Orang Laut proper", elaborated upon in the first section. While the bajak laut crews were ethnically diverse, he argues, none of them were of orang laut ancestry-the latter being considered inferior. In fact, impoverished aquatic populations at the lower end of the power hierarchy were often welcome targets for maritime violence in times of war (Sopher 1965, p. 253; Lapian 1987, p. 34; Young 2004, p. 56). Nevertheless, when necessitated by economic needs or in case they were conquered, orang laut occasionally collaborated with bajak laut in predatory activities, although many would return to their traditional lifestyles when relieved from their duties. The great knowledge of the former of regional currents, islands, winds, location of shoals and reefs gave them a clear advantage over navigators of larger vessels (Andaya 1984, pp. 36, 37, 2008, pp. 177, 178). Lapian (1987, pp. 182, 183, $185)$, however, argues that this does not make them "true pirates", for orang laut communities did not take slaves (but killed their captives instead). ${ }^{6}$ This generalisation appears to be less universal than the author suggests. The Sama-Bajau communities in South Sulawesi, for example, were very much involved in slave-raiding under the patronage of professional bajak laut (cf. Vosmaer 1839), as was the case in the Sulu Archipelago. In fact, the capacities of raja laut and bajak laut-depending upon the circumstances-were frequently adopted by specialised groups of orang laut. As a result of intermarriage with land-based elites, several raja laut of Orang Laut or Sama-Bajau ancestry operated in the waters of insular Southeast Asia. This observation somewhat diminishes the analytical utility of Lapian's distinction. Instead, it may be argued that the distinctions were relatively fluid and that occasional piratical habits of the orang laut are best explained in terms of economic hardship and external subjugation. Frequently confronted with the unavailability of natural resources, after all, their minds were set to exploit everything the sea had to offer, including wayward vessels (Young 2004, pp. 72, 73). The greatest irony, therefore, is that the semi-sedentary maritime communities in Southeast Asia were-and continue to be - an important labour pool for piracy but were also its most significant victims (Sopher 1965, p. 253; Sather 1997, pp. 103, 104; Young 2004, pp. 79, 80, 88).

In recent times, piracy is predominantly associated with either Somalia (by those who follow the global news) or the Caribbean (by those who follow Hollywood's latest blockbusters). However, more than half of all reported cases of piracy take place in

\footnotetext{
${ }^{6}$ In addition, it may be argued that communities had to be shore-dwelling, rather than boat-dwelling, in order to manufacture large ships and become successful pirates (cf. Sopher 1965, p. 88).
} 
Southeast Asia, Indonesia being the world's most piracy-prone country (Campo 2003, pp. 163, 164; Mukundan 2004, p. 10; Eklöf 2006, p. 2; Warren 2007, p. 142). The key regions where piracy is rife have not changed: the South China Sea, Strait of Malacca, Gulf of Thailand and Sulu Sea. What has changed, rather tremendously, is the modus operandi; modern-day pirates are equipped with the latest motor boats, automatic weapons, computers and satellite dishes. By virtue of a strong organisation, substantial financial means and the presence of long, mangrove-edged coastlines obfuscating their whereabouts, these highly professional pirates are often able to outpace and outsmart the patrol boats of the overextended and corrupt Southeast Asian navies. Thus, in Ross Kemp's British Sky Broadcasting Group broadcasted documentary In Search of Pirates (episode 3), we come across an interviewed Indonesian pirate commenting, not without a sense of pride, on his East African colleagues: "Somalians are unsophisticated. They just jump on board and begin to shoot. No! That's not how you do it, no way to hijack a ship at all. Somalian pirates are stupid. They're not in our league. Those Somalians are of a lower class."7

While still heavily involved in attacking fishing boats, raiding merchant vessels, and extorting protection money from non-pirates operating in their territory, Southeast Asian pirates have also tagged into the lucrative businesses of drugs smuggling, kidnapping for ransom, and today's answer to slave trade: the trafficking of illegal immigrants and/or prostitutes. In addition, the Indochina War saw the development of Thai fishermen-turnedpirates victimising Vietnamese boat people, which laid the base for much more professional, ruthless and well-equipped criminal gangs operating in and beyond the Gulf of Thailand (Eklöf 2006, p. 18ff.). The pan-Asian crime syndicates that started to dominate high sea piracy from the 1970s onwards, some of which well-connected to Soeharto's New Order Regime, were led by "well-suited businessmen, sitting in plush offices hidden behind ghost companies, stealing ships and goods, sometimes via the Internet" (Warren 2007, p. 145). The economic insecurity, political instability and ethno-religious conflicts of the late 1990s caused a further boom in maritime crime across Southeast Asia. While piracy has always been transregional, it is becoming globalised in this part of the world, displaying direct links to places as remote as Hongkong, Taiwan, Bangladesh and Papua New Guinea.

Despite some historical analogies, such as the perceptible and predictable increase of piracy in times of drastic socio-economic change, the pirates who now plague the Strait of Malacca are entirely different from their historical antecedents. The role of the nomadic Orang Laut has been reduced to zero, having been replaced by Indonesians from various backgrounds (Eklöf 2006, pp. 49, 58). In the Sulu region, as we have seen, the continuity of traditional power structures is much stronger. As happened centuries ago, powerful syndicates still find sufficient quantities of readily recruitable would-be pirates among the region's impoverished maritime communities. However, several developments have complicated the seascapes of this region. Maritime transport, piracy, regional separatism and terrorism have often blended into new constructs. Illustratively, members of the infamous Abu Sayyaf Group and other outlawed organisations operating in the southern Philippines claim to be Islamic separatists, are regarded as terrorists by the international community and are, in effect, mostly involved with piratical activities (cf. Campo 2003, p. 159; Tokoro 2010, p. 281). The loot of this type of "political piracy" goes directly to the separatist organisation that funds and equips the perpetrators (Eklöf 2006, p. 110ff.),

\footnotetext{
${ }^{7}$ My translation from the original: "Tidak canggih, Somalia. Dia pergi naik lah tetetetetet! Oh bukan! Kalo dia mo kerja bukan begitu, dia ambil satu kapal itu untuk mo sandera. Itu... kalo pirate di Somalia tu pirate yang bodoh itu. Itu tidak dengan kelas kami. Itu kelas-kelas kecil itu Somalia, ya.”
} 
showing remarkable similarities with the patron-client power relations that have characterised this region at least since the era of the Malay sultanates. However, such operations have now reached a global scale and terrorist organisations such as Jemaah Islamiyyah (or, for that matter, al-Qaeda or the LTTE) find few problems infiltrating in the ranks of seafarers to employ cargo containers to transport goods from one place to another (Richardson 2004). Hence, Southeast Asian piracy is starting to merge into a category of much greater concern: maritime terrorism.

This opens up an entirely different question: what is the role and place of religion, especially Islam, in contemporary piracy? Colonial commentators assure us that Islamic leaders considered piracy a special type of sacred war (jihad) and encouraged the slave trade and slave raiding activities of Muslim pirates as long as the victims were nonMuslims (Veth 1870, p. 175; Raffles 1978, pp. 232, 233). Do phenomena such as global jihad and religion-based separatism provided similar types of justification for modern pirates in Southeast Asia and beyond (cf. Eklöf 2006, p. 123)? Needless to say, most Muslims find very few excuses for piracy whatsoever, although several contrasting perspectives and interpretations remain. Technically, Islamic law (shariah) has it that Muslims are obliged to combat piracy in coastal seas and protect ships in these waters, including those operated by non-Muslims (Khalilieh 1998, pp. 128-148). In Somalia, Islamic leaders have indeed frequently denounced piracy and the predominance of Islamists insurgent groups such as Hizbul Islam has sparked a decline of piracy in certain regions. On the other hand, a shared religion did not stop the Somalian pirates from hijacking the Indonesian ship Sinar Kudus in 2011, although the Indonesian ship crew were apparently given a better treatment than the many non-Muslim victims that East African piracy has claimed over the last decades (Azwar 2011; Drama 2011). Certainly, the topic of religion in modern piracy still leaves many interesting questions unanswered.

\section{Conclusion}

Southeast Asia forms a valuable case study of the historical importance of water, an element able to connect and isolate people, shape and reshape long-standing power relations, and facilitate trade and expansion beyond the confines of terra firma. The roles of its seascapes and the maritime communities inhabiting them are multilayered, dynamic and highly susceptible to change. Thus, while early 20th-century ethnographies depict the nomadic maritime communities of Southeast Asia as timid, elusive people, in pre-modern times they functioned as powerful intermediates between the land-based merchant-kings and their maritime hinterland or "maritory". Partly by virtue of these "sea people", early Malay and other insular Southeast Asian states proved interesting enough to participate in long-distance commercial networks with China and the Indian Ocean regions. Eventually, the European hegemony of Southeast Asia brought an end to the importance of these communities when the Malay states and other maritime-oriented political entities lost their control over the seas and started to adopt land-based lifestyles, breaking with a much longer history of nautical activities, skills and traditions.

As the services and marine expertise of "sea people" are now no longer required, at least not on a scale comparable to the era of the Malay kingdoms, their descendants face the choice of assimilating into mainstream, land-based populations or continuing to pursue an increasingly marginalised maritime lifestyle. Many of them do not have access to capital, modern equipment, education and healthcare. Although this situation has forced a relatively small group into illegal practices, such as maritime terrorism and 
what has been labelled "environmental terrorism" (fish-bombing, cyanide poisoning, etc.), the majority remains predominantly involved in boat-building and small-scale fishing activities, despite the ongoing pollution and destruction of their marine environment, competition from better equipped fishing companies, the increasing number of "no-take" zones where fishing is prohibited, and-in some regions-the structural danger of being victimised by professional pirate groups. Piracy itself has also evolved; it has taken on westernised, globalised shapes. While partly legitimate in the Southeast Asian past, today's static territorial borders and global reliance on intercontinental sea trade have completely and conclusively outlawed the practice of maritime raiding. Nevertheless, the patron-client type of power consolidation and the marginal position of poor fishermen within these networks have changed very little. For these marginalised communities trapped in an ongoing and increasingly difficult struggle for survival, the pull factors into piracy largely remain as relevant today as they were during colonial and pre-colonial times. Indeed, this very practice can and should never be disconnected from more general socio-economic developments, in Southeast Asia and in other parts of the world alike.

Several puzzle pieces of Southeast Asia's seascapes remain unsolved. The Myanmar government continues to discourage any attempt to seriously study the peripheral Moken communities inhabiting the Mergui Archipelago, leaving us largely with secondary and presumably outdated information complemented with some quick snapshots taken, from a chartered speedboat, by the occasional tourist in an attempt to contact the "uncontacted". In addition, the ways in which local maritime networks are influenced by and incorporated into global networks - through joint navy operations, pan-Islamic terrorist organisations, economical networks expanding across the Pacific Rim, human trafficking syndicates, and tourism-fall beyond the scope of this study. In general, it has become increasingly clear that terms such as "piracy", "slavery", "terrorism" and "ethnicity" refer to something quite different in this part of the world and one may wonder if these categories sufficiently equip us to deal with this region's complicated past and present. The question of who Southeast Asia's historical "sea people" were-and are-is not an easy one to answer. These communities continue to display considerable internal differences in terms of lifestyle, ethnolinguistic affiliation and socio-political status. The cultural-historical dynamics highlighted in this article explain how entire groups of people can evolve from peaceful traders to fearsome pirates and from fearsome pirates to elusive boat-dwellers. To be a part of them involves being a part of their maritime universe, actively participating in their cultural practices, and appreciating their conceptualisation of life and the environment. That being said, truly nomadic maritime hunter-gatherers are on the verge of extinction, not only in Southeast Asia but everywhere in the world. Consequently, their moribund maritimity should motivate and compel us to learn more about these people and their unwritten past, before their inevitable assimilation into the land-bound mainstream has reached completion.

Acknowledgments This study has greatly benefitted from valuable discussions I was privileged to have on many of the topics addressed. In particular, I would like to thank Agus Supiani, Christopher Hale, Datuk Malali, Dea Edensor, Fatimah, Haris Ibrahim, Junki Suaka, Marlina, Mohamad Said Hinayat, Mutiara Wati, Pardiansyah and Rasyid Bafadal. Further, I would like to specially thank Helen Brunt, Nicole Boivin, Waruno Mahdi and two anonymous reviewers for their insightful comments on earlier versions of this article and suggestions for improvements. I am also indebted to the European Research Council for their financial support. 
Open Access This article is distributed under the terms of the Creative Commons Attribution License which permits any use, distribution, and reproduction in any medium, provided the original author(s) and the source are credited.

\section{References}

Aichele W (1954) Sprachforschung und Geschichte im indonesischen Raum. Oriens Extremus 1:107-122 Andaya LY (1975) The kingdom of Johor: 1641-1728. Oxford University Press, Kuala Lumpur

Andaya LY (1984) Historical links between the aquatic populations and the coastal peoples of the Malay World and Celebes. In: Abu Bakar M, Kaur A, Ghazali AZ (eds) Historia: essays in commemoration of the 25th anniversary of the department of history university of Malaya. The Malaysian Historical Society, Kuala Lumpur, p 34-51

Andaya LY (2008) Leaves of the same tree: trade and ethnicity in the Straits of Melaka. University of Hawaii Press, Honolulu

Astuti R (1995) People of the sea: identity and descent among the Vezo of Madagascar. Cambridge University Press, Cambridge

Azwar AS (2011) Kesabaran perompak Somalia menipis, ABK kapal Sinar Kudus depresi. Media Indonesia. com, 12 April 2011. http://www.mediaindonesia.com/read/2011/04/04/217358/284/1/-Kesabaran-PerompakSomalia-Menipis-ABK-Kapal-Sinar-Kudus-Depresi. Accessed 17 Feb 2012

Barker G and Rabett R (2009) Late Pleistocene and early Holocene forager mobility in Southeast Asia. In: Presented at the 19th congress of the Indo-Pacific prehistory association (IPPA), Hanoi, 29 Nov-5 Dec 2009

Bijdrage (1858) Bijdrage tot de kennis van den Maleischen zeeroover. Tijdschrift voor Nederlandsch Indië 20(1):77-90

Blust R (2006) The linguistic macrohistory of the Philippines: some speculations. Paper presented at the 10th international conference on Austronesian Linguistics (10-ICAL), Puerto Princesa City, Palawan, 17-20 Jan 2006

Boomgaard P (2007) In a state of flux: water as deadly and a life-giving force in Southeast Asia. In: Boomgaard P (ed) A world of water: rain, rivers and seas in Southeast Asian histories. KITLV Press, Leiden, p 1-23

Boutin ME and Soderberg CD (2009) An overview of linguistic research on the Sama-Bajau languages in Malaysia. Preliminary draft

Bulbeck D (2004) Indigenous traditions and exogenous influences in the early history of Peninsular Malaysia. In: Glover I, Bellwood P (eds) Southeast Asia: from prehistory to history. Routledge Curzon, London, New York, p 314-336

Campo JNFMà (2003) Gauging the historical dimension of globalization: the case of maritime piracy in insular Southeast Asia. Int J Marit His 15(1):159-175

Chou C (2003) Indonesian sea nomads: money, magic, and fear of the Orang Suku Laut. Routledge Curzon, London

Chou C (2010) The Orang Suku Laut of Riau, Indonesia. Routledge, London, New York

Dahl OC (1991) Migration from Kalimantan to Madagascar. Norwegian University Press, Oslo

Damais LC (1968) Études soumatranaises. III. La langue B des inscriptions de Śrī Wijaya. Bulletin de l'École Française d'Extrême Orient 54:523-566

Drama (2011) Drama dibalik penyelamatan Sinar Kudus di Somalia. Korando-Koran Anak Indonesia, 22 Mei 2011. http://korandoanakindonesia.wordpress.com/2011/05/22/drama-dibalik-penyelamatan-sinarkudus-di-somalia. Accessed 17 Feb 2012

Eklöf S (2006) Pirates in paradise: a modern history of Southeast Asia's maritime marauders. NIAS Press, Copenhagen

Ferrand MG (1932) Quatre textes éphigraphiques malayo-sanskrits de Sumatra et de Banka. J Asiat (11th Se) $221: 271-326$

Haddon AC (1920) The outriggers of Indonesian canoes. J Roy Anthr Inst Gb Ir 50:69-134

Gupta S (2007) Piracy and trade on the western coast of India (AD 1-250). Azania Archaeol Res Afr 42 (1):37-51

Hamzah AB (1995) Some historical accounts on the Sulu/Brunei Sultanate and the Bajau community. Paper presented at the international conference on Bajau/Sama community "Bajau-Meniti Zaman" (progress through the ages), Kota Kinabalu, 24-28 June 1995

Harrisson T (1976) Ngaju-Bajau: significant early term usages in Southeast Asia (especially Malaysia). J Malay Branch R Asiat Soc 49(1):1-14 
Hogan DW (1988) Urak Lawoi': basic structures and a dictionary. In collaboration with Stephen W. Pattemore. Pacific Linguistics, Canberra

Hoogervorst T (2012) Southeast Asia in the ancient Indian Ocean World: combining historical linguistic and archaeological approaches. Dissertation, University of Oxford, Oxford

Hope S (2001) Outcasts of the islands: the sea gypsies of South East Asia. Harper Collins, London

Ivanoff J (1989) Moken: les naufrages de l'histoire; une société de nomades marins de l'archipel de Mergui. Ecole des Hautes Etudes en Sciences Sociales. Dissertation

Kähler H (1960) Ethnographische und linguistische Studien über die Orang darat, Orang akit, Orang laut und Orang utan im Riau-Archipel und auf den Inseln an der Ostküste von Sumatra. Reimer Verlag. Veröffentlichungen des Seminars für Indonesische und Südseesprachen der Universität Hamburg 2, Berlin

Khalilieh HS (1998) Islamic maritime law. Brill, Leiden

Kniphorst JHPE (1875) Historische schets van den zeeroof in den Oost-Indischen Archipel. Draft presented to Tijdschrift voor het zeewezen

Kortschak I (2010) Invisible people: poverty and empowerment in Indonesia. Godown, Jakarta

Lamster JC (1937) Zeenomaden in den archipel. Onze Aarde 10:263-272

Lape PV, O'Connor S, Burningham N (2007) Rock Art: a potential source of information about past maritime technology in the South-east Asia-Pacific region. Int J Naut Archaeol 36(2):238253

Lapian AB (1987) Orang Laut-Bajak Laut-Raja Laut: sejarah kawasan Laut Sulawesi abad XIX. Universitas Gadjah Mada, Yogyakarta

Lapian AB, Kazufumi N (1996) Research on Bajau communities: maritime people in Southeast Asia. Asian Res Trends 6:45-70

Luce GH (1965) Rice and religion: a study of Old Mon-Khmer evolution and culture. J Siam Soc 53(1): $139-152$

Mack J (2007) The land viewed from the sea. Azania Archaeol Res Afr 42(1):1-14

Mahdi W (1999) Linguistic and philological data towards a chronology of Austronesian activity in India and Sri Lanka. In: Blench R, Springs M (eds) Archaeology and Language IV: language change and cultural transformation. Routledge, London, New York, p 160-242

Mahdi W (2008) Yavadvipa and the Merapi Volcano in West Sumatra. Archipel 75:111-143

Mahdi W (2009) In search of an historical sea-people Malay dialect with aba. In: Adelaar A, Pawley A (eds) Austronesian historical linguistics and culture history: a festschrift for Robert Blust. Pacific Linguistics Series 601, Canberra, p 73-89

Martenot A (1981) Bateaux Sama de Sitangkai. Archipel 22:183-207

Maspéro G (1928) Le royaume de Champa. Van Oust, Paris, Brussels

Matthes BF (1872) Eenige opmerkingen omtrent en naar aanleiding van dat gedeelte van Dr. J.J. de Hollander's Handleiding bij de Beoefening der Land-en Volkenkunde van Nederlansch Oost-Indië, hetwelk handelt over het Gouvernement van Celebes en Onderhoorigheden. Bijdragen tot de Taal-, Land-en Volkenkunde van Nederlansch-Indië 19:1-91

Mukundan P (2004) Scourge of piracy in Southeast Asia-any improvements in 2004? In: Richardson M, Mukundan P (eds) Political and security outlook 2004: maritime terrorism and piracy. Institute of Southeast Asian Studies, Singapore, p 9-18

Nicholl R (1972) The mission of father Antonio Vantimiglia to Borneo. Brunei Mus J 2:183-203

Nicholl R (1977) Relations between Brunei and Manila A.D. 1682-1690. Brunei Mus J 4(1): $128-176$

Obdeijn V (1943) Volk en taal der oude Maleise rijken in Zuid-Sumatra. Tijdschrift van het Koninklijk Nederlandsch Aardrijkskundig Genootschap (2nd Ser) 60:706-723

Ormerod HA (1978) Piracy in the ancient world. Liverpool University Press, Liverpool

Pallesen AK (1977) Culture contact and language convergence. Dissertation, University of California, San Francisco

Peralta JT (1995) Prehistoric links of the Sama lepa of Tawi-Tawi province, Philippines. Paper presented at the international conference on Bajau/Sama community "Bajau-Meniti Zaman" (progress through the ages), Kota Kinabalu, 24-28 June 1995

Prins AHJ (1965) Sailing from Lamu: a study of maritime culture in Islamic East Africa. Van Gorcum, Assen

Raffles TS (1978) The history of Java. Oxford University Press, Kuala Lumpur (reprint)

Richardson M (2004) Terrorism: the maritime dimension. In: Richardson M, Mukundan P (eds) Political and security outlook 2004: maritime terrorism and piracy. Institute of Southeast Asian Studies, Singapore, p $1-7$ 
Rutter O (1986) The pirate wind; tales of the sea-robbers of Malaya. Oxford University Press, Singapore (reprint)

Saat G (2008) Implikasi politik melayuisme Sama-Bajau di Malaysia. Sari 26:63-70

Sather CA (1995) Sea nomads and rainforest hunter-gatherers: foraging adaptations in the Indo-Malaysian Archipelago. In: Bellwood P, Fox JJ, Tryon D (eds) The Austronesians: historical and comparative perspectives. Australian National University, Canberra, pp 229-268

Sather CA (1997) The Bajau Laut: adaptation, history, and fate in a maritime fishing society of Southeastern Sabah. Oxford University Press, Kuala Lumpur

Schot JG (1884) Het stroomgebied der Kateman: bijdrage tot de kennis van Oost-Sumatra. Tijdschrift voor Indische Taal-, Land-en Volkenkunde 29:555-581

Scott WH (1980) Boat building and seamanship in classic Philippine society. Anthropological papers 9. National Museum, Manila

Sheriff A (2010) Dhow cultures of the Indian Ocean: cosmopolitanism, commerce and Islam. Hurst \& Company. Zanzibar Indian Ocean Research Institute, London

Sopher DE (1965) The sea nomads: a study based on the literature of the maritime boat people of Southeast Asia. Syracuse University, Memoirs of the National Museum 5, Syracuse

Tarling N (1963) Piracy and politics in the Malay world: a study of British imperialism in nineteenthcentury South-East Asia. F.W. Cheshire, Melbourne/Canberra/Sydney

Tokoro I (2010) Piracy in contemporary Sulu: an ethnographical case study. In: Kleinen J, Osseweijer M (eds) Pirates, ports, and coasts in Asia: historical and contemporary perspectives. International Institute for Asian Studies, Leiden and Institute of Southeast Asian Studies, Singapore, p 269-287

Veth PJ (1870) De heilige oorlog in den Indischen Archipel. Tijdschrift voor Nederlandsch Indië (3rd Ser) 4 (1):167-176

Vosmaer JN (1839) Korte beschrijving van het zuid-oostelijk schiereiland van Celebes. Verhandelingen van het Bataviaasch Genootschap van Kunsten en Wetenschappen 17:63-184

Warren JF (2002) Iranun and Balangingi: globalization, maritime raiding and the birth of ethnicity. Singapore University Press, Changi

Warren JF (2007) A tale of two centuries: the globalization of maritime raiding and piracy in Southeast Asia at the end of the eighteenth and twentieth centuries. In: Boomgaard P (ed) A world of water: rain, rivers and seas in Southeast Asian histories. KITLV Press, Leiden, pp 125-152

Wolters OW (1967) Early Indonesian commerce: a study of the origins of Srivvijaya. Cornell University Press, Ithaca

Wright L (1979-80) The Lanun pirate states of Borneo: their relevance to Southeast Asian history. Sabah Soc J 6(4):207-217

Yesner DR, Ayres WS, Carlson DL, Davis RS, Dewar R, Morales MRG, Hassan FA, Hayden B, Lischka JJ, Sheets PD, Osborn A, Pokotylo DL, Rogers T, Spanier E, Turner BL II, Wreschner EE (1980) Maritime hunter-gatherers: ecology and prehistory. Curr Anthropol 21(6):727-750

Young AJ (2004) Roots of contemporary maritime "piracy" in Southeast Asia. MA thesis, University of Hawaii, Honolulu

Young AJ (2005) Roots of contemporary maritime piracy in Southeast Asia. In: Johnson D, Valencia M (eds) Piracy in Southeast Asia: status, issues, and responses. Institute of Southeast Asian Studies, Singapore, p 1-33

Zacot F (1978) To be or not to be Badjo: this is our question. Prisma Indo J Soc Econ Aff 10:17-29

\section{Author Biography}

Tom Gunnar Hoogervorst is a lecturer at the Leiden Institute of Areal Studies, University of Leiden. He is currently completing a DPhil Dissertation at the University of Oxford on linguistic evidence for longdistance prehistoric trade networks in the Indian Ocean. His interests include historical linguistics, maritime archaeology, Southeast Asian studies and the Malay language and literature. 